2018

Reply to: Punctuated transgression (?): Comment on Oliver, T.S.N., Donaldson, P., Sharples, C., Roach, M., and Woodroffe, C.D. "Punctuated progradation of the Seven Mile Beach Holocene barrier system, southeastern Tasmania"

Thomas S. Oliver

University of Wollongong, toliver@uow.edu.au

Paul Donaldson

University of Tasmania (UTAS), BTM WBM

Michael Roach

University of Tasmania

Colin D. Woodroffe

University of Wollongong, colin@uow.edu.au

Chris Sharples

BMT WBM, University of Tasmania

\title{
Publication Details
}

Oliver, T. S.N., Donaldson, P., Roach, M., Woodroffe, C. D. \& Sharples, C. (2018). Reply to: Punctuated transgression (?): Comment on Oliver, T.S.N., Donaldson, P., Sharples, C., Roach, M., and Woodroffe, C.D. "Punctuated progradation of the Seven Mile Beach Holocene barrier system, southeastern Tasmania". Marine Geology, 405 131-133. 


\title{
Reply to: Punctuated transgression (?): Comment on Oliver, T.S.N., Donaldson, P., Sharples, C., Roach, M., and Woodroffe, C.D. "Punctuated progradation of the Seven Mile Beach Holocene barrier system, southeastern Tasmania"
}

\begin{abstract}
Our interpretation of the depositional history of the prograded barrier at Seven Mile Beach in Tasmania, described in Oliver et al. (2017a), was based on the morphology of ridges apparent in the LiDAR-based digital elevation data and a sample of 14 optically-stimulated luminescence (OSL) ages. Dougherty (2018) has identified gaps in the chronology and speculated that progradation may have occurred as sea level fell from a mid-Holocene highstand inappropriately applying sea-level curves from mainland Australia. Despite a highstand being inferred by early research in Tasmania, glacio-isostatic modelling and recent sea-level studies adopted a prevailing view that excluded a highstand. Our observations led us to question this prevailing view and to suggest that it might be appropriate to reopen the debate on Holocene sea-level change in Tasmania. We welcome the renewed interest in the chronology and sea-level history of this prograded barrier, and look forward to further clarification based on new evidence. The site may have the potential to become one of the more continuous and better-constrained sea-level records in southern Australia.
\end{abstract}

\section{Keywords}

system, southeastern, tasmania", punctuated, transgression, (?):, comment, oliver, t.s.n., donaldson, p., sharples, c., roach, m., woodroffe, reply, c.d., to:, "punctuated, progradation, seven, mile, beach, holocene, barrier

\section{Publication Details}

Oliver, T. S.N., Donaldson, P., Roach, M., Woodroffe, C. D. \& Sharples, C. (2018). Reply to: Punctuated transgression (?): Comment on Oliver, T.S.N., Donaldson, P., Sharples, C., Roach, M., and Woodroffe, C.D. "Punctuated progradation of the Seven Mile Beach Holocene barrier system, southeastern Tasmania". Marine Geology, 405 131-133. 
1 Reply to: Punctuated Transgression (?): Comment on Oliver, T.S.N., Donaldson, P., Sharples,

2 C., Roach, M., and Woodroffe, C.D. "Punctuated progradation of the Seven Mile Beach

3 Holocene barrier system, southeastern Tasmania"

4 Oliver, T.S.N., ${ }^{1,4}$ Donaldson, P., ${ }^{2}$ Roach, M., ${ }^{3}$ Woodroffe, C.D., ${ }^{4}$ Sharples, C. ${ }^{5}$

$5 \quad{ }^{1}$ School of Physical, Environmental and Mathematical Sciences, The University of New South Wales at the

6 Australian Defence Force Academy, Northcott Drive, Canberra, ACT, 2610, Australia

$7 \quad 2$ BMT, Newcastle, NSW 2292, Australia

$8 \quad{ }^{3}$ ARC Centre of Excellence in Ore Deposits, University of Tasmania, Tasmania, Australia

$9{ }^{4}$ School of Earth and Environmental Science, University of Wollongong, Northfields Ave, Wollongong, NSW, 10 2522, Australia

$11{ }^{5}$ Geography and Environmental Studies, University of Tasmania, Tasmania, Australia

12 Abstract

Our interpretation of the depositional history of the prograded barrier at Seven Mile Beach in Tasmania, described in Oliver et al. (2017a), was based on the morphology of ridges apparent in the LiDAR-based digital elevation data and a sample of 14 optically-stimulated luminescence (OSL) ages. Dougherty (2018) has identified gaps in the chronology and speculated that progradation may have occurred as sea level fell from a mid-Holocene highstand inappropriately applying sea level curves from mainland Australia. Despite a highstand being inferred by early research in Tasmania, glacio-isostatic modelling and recent sea-level studies lead to a prevailing view that excluded a highstand. Our observations led to us question this prevailing view and to suggest that it might be appropriate to reopen the debate on Holocene sea-level change in Tasmania. We welcome the renewed interest in the chronology and sea-level history of this prograded barrier, and look forward to further clarification based on new evidence. The site may have the potential to become one of the more continuous and better-constrained sea-level records in southern Australia.

\section{Introduction}

We welcome the opportunity to clarify our interpretation of the Holocene depositional history of the Seven Mile Beach prograded barrier system in southeastern Tasmania, outlined in Oliver et al. (2017a). Dougherty (2018) has raised a series of concerns about the paper, questioning the use of the phrase 'punctuated progradation' and identifying a series of data gaps and discrepancies. We adopted the phrase 'punctuated progradation' to refer to the pauses, or periods of slow shoreline progradation identified at this site. We had not intended to refer to the reflections seen in ground-penetrating radar (GPR) profiles that may represent individual storm events; our usage was in the context of shoreline behaviour (Cattaneo \& Steel, 2003), referring to periods of relatively slow progradation or periods of "coastal retreat or coastal reorganization" (Clemmensen et al. 2012 p. 433). We adopt the term 
'pause' herein to avoid any further confusion. Dougherty (2018) raises concerns about three of these phases 1) the pause in progradation between 6500 and 3500 years ago, 2) the rapid progradation from 3500 to 1500 years ago, and 3) shoreline behaviour and transgressive dune development between 1500 years ago and present. We address each of these concerns in turn and offer several thoughts and responses in relation to sea-level history.

\section{Data gaps and discrepancies}

Dougherty (2018) posited several gaps and discrepancies in the chronology presented in Oliver et al. (2017a). Further dating of specific features of the barrier would certainly continue to inform the pattern of progradation at this site. The discontinuous topographic profiles were initially examined in Donaldson (2010) as part of a BSc Honours project; this is the primary source of the radar data and provides a more precise indication of the radar profile start and end points. Donaldson attempted to acquire GPR data across the entire barrier, but access through the publicly accessible pine plantation was frustrated by fallen vegetation and data quality was severely compromised by numerous high amplitude diffractions due to tree roots. As clearly indicated in Fig. 1a of Oliver et al. (2017a), there is a substantial variation in the cross-shore barrier morphology that cannot be captured by a single topographic profile. We undertook two separate field campaigns of OSL sample collection specifically to refine the chronology of the ridges, but our suite of 14 ages obviously provides only a broad picture of depositional history. The sample dated $3250 \pm 150$ near GPR profile BR6 in Fig. 1 of Oliver et al. (2017a) was collected to test whether the samples in the eastern portion of the barrier could be traced alongshore to the west as the perceived pause in progradation corresponded to the horizontal offset between the OSL dating transects. This exercise confirmed the alongshore continuity of the ridge chronology and in so doing established the pause in progradation in which only the 2 “higher' ridges formed.

\subsection{Pause in progradation between $\sim 6500$ and $\sim 3500$ years ago}

Dougherty (2018) questions the pause in progradation that we identified between the ridges dated to 6750 and 3600 years ago, pointing out that there are two larger ridges (around $0.5 \mathrm{~m}$ higher than those to either side) that formed during the pause. This was stated in the original paper: "During this time period, only two slightly larger ridges are preserved and there is a low-angle truncation in ridge alignment." (Oliver et al. 2017a p. 84). The pause was also referred to as "an apparent 23000 year phase of substantially reduced progradation rate from $\sim 6750$ to $\sim 3600$ years ago" (Oliver et al. 2017a p. 83). Our point was that progradation slowed rather than ceased.

\subsection{Rapid progradation from 3500 to 1500 years ago and its relation to sea-level fall from highstand}

Dougherty (2018) has suggested that the switch to rapid progradation observed at Seven Mile Beach in Tasmania 2500 years ago is related to a fall from a sea-level highstand in this region. Much of the 
argument by Dougherty (2018) is based on comparison with the chronology of prograded barriers in southern New South Wales. Dougherty (2018) states of Wonboyn, Boydtown and Seven Mile Beach, Tasmania that "all display a shift to rapid progradation starting between 3 and $4 \mathrm{ka}$, which possibly captures the uniform timing of a fall from a mid-Holocene highstand" (Dougherty 2018 p.4). We do not consider it appropriate to adopt a sea-level curve from New South Wales (NSW) and apply it in this way to Tasmania, and discuss this in more detail below. Furthermore, we do not consider it useful to compare the chronologies of beach-ridge deposition, as we have found that individual prograded barrier systems in southern NSW appear to have undergone considerably different patterns of progradation (Oliver et al. 2017b; 2017c).

\subsection{Shoreline behaviour and transgressive dune development between 1500 years ago and present}

Dougherty (2018) speculates on the pattern of deposition over the past few centuries. The most seaward of the OSL samples reported in Oliver et al. (2017a) returned an age of $\sim 1400$ years and is approximately $400 \mathrm{~m}$ inland of the present-day shoreline; the absence of ages over the past millennium (with the exception of a single age from the top of the large transgressive dune that has formed in that time) obviates any firm conclusions. For the shoreline to have reached its present position there must have been some progradation after $\sim 1400$ years and the GPR-imaged subsurface structures confirm this. We adopted the progradation rate established between 3500-1400 years to estimate that the shoreline could have reached its position by around 500 years ago. As Dougherty (2018) points out, progradation may have been slower during this time, meaning the shoreline may have taken longer to reach its present position, or it may have exceeded its present position and subsequently retreated. Several more OSL ages might help to determine the shoreline behaviour during this time frame, but it is clear that this represents a different phase in the evolution of the barrier, and one for which we presently have minimal age control. We suggest that any further consideration of the recent barrier history should thoroughly investigate all possible causes of the large transgressive dune and high foredune, including disturbance such as vegetation removal and grazing (e.g. Kurnell, Sydney) in addition to changes in sea level and sediment availability.

\section{Mid to late Holocene sea level in Tasmania}

A central feature of the arguments put forward by Dougherty (2018) is the suggestion that the sea was higher than present and that 'sea-level fall is a plausible mechanism to force an increase in progradation'. Dougherty (2018) recognises that the sea-level history of Tasmania is not well studied, and that a review of postglacial sea-level change in Australia by Lewis et al. (2013) left Tasmania out because of the scarcity of data. However, Dougherty (2018) does not appear to realise that the prevailing view is that there was not a highstand during the Holocene. We believe that it is inappropriate to adopt the sea-level curve derived for NSW by Sloss et al. (2007) and still more 
incorrect to use one from Queensland (QLD), such as that compiled by Lewis et al. (2013), in view of regional variability in glacio-isostatic adjustment.

Evidence for a Holocene highstand in Tasmania has been elusive (Lewis et al., 2013). Davies (1958; 1959 ; 1961) proposed higher sea levels during the Holocene using the crests and swales of stranded foredune ridges at several sites in Tasmania, and proposed a fall in sea level of $\sim 1 \mathrm{~m}$ at Seven Mile Beach, Tasmania (see also Oliver et al. (2017c) for discussion). Glacio-isostatic adjustment (GIA) modelling by Lambeck and Nakada (1990) implied no highstand in Tasmania noting the potential influence of Late Pleistocene uplift also suggested by Murray-Wallace \& Goede (1991; 1995). This interpretation appears to be the prevailing view (Lambeck, 2002), and recent proxy reconstructions have favoured a sea level that remained below present level in mid Holocene but rose gradually to its present level (Gehrels et al., 2012; Morrison \& Ellison, 2017).

Clark et al. (2011) also concluded that the sea level was below present around 7000 years ago, but they did infer a fall in sea-level during the late Holocene to explain the decreasing marine influence observed in three coastal wetlands. Some sites were examined by Donaldson (2010) which might indicate higher sea levels in this region, for example, raised backbarrier deposits of inferred Holocene-age some $1.4 \mathrm{~km}$ north of the most landward ridges at Seven Mile Beach. Also during field campaigns, a wave deposited shelly horizon at $\sim 1.5 \mathrm{~m}$ above mean high water level was observed exposed within the eroded ridge stratigraphy at Five Mile Beach. Before a sea-level highstand can be asserted for Tasmania, precise dating of these sea-level proxies around Tasmania's coasts is needed as originally stated in Donaldson (2010). Without chronological information for these sites, we chose to cautiously foreshadow that "progradation from $\sim 3500$ onwards may have been due to a LateHolocene sea-level fall from a high stand in the mid Holocene" (Oliver et al. 2017a, p. 86) while also asserting that "it may also be appropriate to reopen the debate on Holocene sea-level change in Tasmania" (Oliver et al. 2017a, p. 76).

We are pleased to see that this debate on Holocene sea level has been reopened. We have discussed the potential for deriving a sea-level history from these former beach deposits at this site with Dougherty in the field. Dougherty has pioneered the extraction of detailed sea-level histories from GPR records elsewhere (Dougherty 2014; Dougherty \& Dickson, 2012). Seven Mile Beach barrier appears to provide an ideal research site to investigate sea-level history over past millennia with much of the shell-bearing beach unit being exposed along the eroding shoreline of Five Mile Beach.

\section{Conclusion:}

Further investigation of the prograded barrier at Seven Mile Beach in Tasmania could potentially resolve several questions regarding the interplay of sea-level change, sediment supply, shoreline behaviour and barrier morphology. Dougherty (2018) has raised several concerns and postulated that barrier progradation may have been related to a fall of sea level from a mid to late Holocene 
highstand. In our paper (Oliver et al. 2017a), we concluded by stating that this site could reopen the debate on Holocene sea level around Tasmania, as was foreshadowed by Donaldson (2010). Dougherty speculates that the sea was higher at this site inappropriately applying a sea-level curve from NSW and QLD. While this is an interesting hypothesis, it remains conjectural until the evidence is presented to substantiate this claim. We believe that careful analysis of field sections, extended across the barrier using GPR, could reveal that there was a higher sea level here throughout mid-late Holocene. Indeed, there could be a continuity of record across 6 to 7 millennia which might make this one of the better constrained sea-level records in southern Australia. We look forward to seeing evidence to confirm this. Meanwhile, the influence of sea-level change on the barrier evolution at Seven Mile Beach will remain in question until such mid-late Holocene sea-level history has been adequately documented.

\section{Acknowledgements:}

Colin Murray-Wallace kindly read through a draft of this manuscript.

\section{References:}

Cattaneo, A., \& Steel, R. J. (2003). Transgressive deposits: A review of their variability. EarthScience Reviews, 62(3-4), 187-228.

Clark, K., Cochran, U., \& Mazengarb, C. (2011). Holocene coastal evolution and evidence for paleotsunami from a tectonically stable region, Tasmania, Australia. The Holocene 21, 883895.

Clemmensen, L. B., Nielsen, L., Bendixen, M., \& Murray, A. (2012). Morphology and sedimentary architecture of a beach-ridge system (Anholt, the Kattegat sea): A record of punctuated coastal progradation and sea-level change over the past $\sim 1000$ years. Boreas, 41(3), 422-23

Davies, J.L. (1958). Analysis of height variation in sand beach ridges. Australian Journal of Science $21,51-52$.

Davies, J. L. (1959). Sea level change and shoreline development in southeastern Tasmania. Papers and Proceedings of the Royal Society of Tasmania, 93, 89-95.

Davies, J. L. (1961). Tasmanian beach ridge systems in relation to sea level. Papers and Proceedings of the Royal Society of Tasmania, 95, 35-41.

Donaldson, P. (2010). Facies Architecture and Radar Stratigraphy of Seven Mile Spit, Tasmania. Unpublished B.Sc. Hons thesis, University of Tasmania. 
Dougherty, A. J. (2014). Extracting a record of Holocene storm erosion and deposition preserved in the morphostratigraphy of a prograded coastal barrier. Continental Shelf Research, 86, 116131.

Dougherty, A.J. (2018) Punctuated Transgression (?): Comment on Oliver, T.S.N., Donaldson, P., Sharples, C., Roach, M., and Woodroffe, C.D. "Punctuated progradation of the Seven Mile Beach Holocene barrier system, southeastern Tasmania”. Marine Geology

Dougherty, A.J. \& Dickson, M.E. (2012). Sea level and storm control on the evolution of a chenier plain, Firth of Thames, New Zealand. Marine Geology 307-310, 58-72.

Gehrels, W. R., Callard, S. L., Moss, P. T., Marshall, W. A., Blaauw, M., Hunter, J., Milton, A.J., Garnett, M. H. (2012). Nineteenth and twentieth century sea-level changes in Tasmania and New Zealand. Earth and Planetary Science Letters, 315-316, 94-102.

Lambeck, K. (2002). Sea level change from mid Holocene to Recent time: An Australian example with global implications. In Ice Sheets, Sea Level and the Dynamic Earth (Vol. 29, pp. 33$50)$.

Lambeck, K., \& Nakada, M. (1990). Late Pleistocene and Holocene sea-level change along the Australian coast. Palaeogeography, Palaeoclimatology, Palaeoecology, 89(1-2), 143-176.

Lewis, S. E., Sloss, C. R., Murray-Wallace, C. V., Woodroffe, C. D., \& Smithers, S. G. (2013). Postglacial sea-level changes around the Australian margin: a review. Quaternary Science Reviews, 74, 115-138.

Morrison, B. V, \& Ellison, J. C. (2017). Palaeo-Environmental Approaches to Reconstructing Sea Level Changes in Estuaries. In K. Weckström, K. M. Saunders, P. A. Gell, \& C. G. Skilbeck (Eds.), Applications of Paleoenvironmental Techniques in Estuarine Studies (pp. 471-494). Dordrecht: Springer Netherlands.

Murray-Wallace, C. V, \& Goede, A. (1991). Aminostratigraphy and electron spin resonance studies of late Quaternary sea level change and coastal neotectonics in Tasmania, Australia. Zeitschrift für Geomorphologie, 35, 129-149.

Murray-Wallace, C. V., \& Goede, a. (1995). Aminostratigraphy and electron spin resonance dating of Quaternary coastal neotectonism in Tasmania and the Bass Strait islands. Australian Journal of Earth Sciences, 42, 51-67.

Oliver, T. S. N., Donaldson, P., Sharples, C., Roach, M., \& Woodroffe, C. D. (2017a). Punctuated progradation of the Seven Mile Beach Holocene barrier system, southeastern Tasmania. Marine Geology, 386, 76-87. 
Oliver, T. S. N., Tamura, T., Hudson, J. P., \& Woodroffe, C. D. (2017b). Integrating millennial and interdecadal shoreline changes: Morpho-sedimentary investigation of two prograded barriers in southeastern Australia. Geomorphology, 288, 129-147.

Oliver, T. S. N., Thom, B. G., \& Woodroffe, C. D. (2017c). Formation of beach-ridge plains: an appreciation of the contribution by Jack L. Davies. Geographical Research, 55(3), 305-320.

Sloss, C. R., Murray-Wallace, C. V., \& Jones, B. G. (2007). Holocene sea-level change on the southeast coast of Australia: a review. The Holocene, 17(7), 999-1014. 